\title{
INTEREST RATE AND EXCHANGE RATE VOLATILITY AND THE PERFORMANCE OF THE NIGERIAN INFORMAL SECTOR: EVIDENCE FROM SMALL AND MEDIUM-SIZED ENTERPRISES
}

\author{
Henry Osahon Osazevbaru* \\ Department of Business Administration, Faculty of the Social Sciences, Delta State University, \\ Abraka, Nigeria
}

This paper investigates the joint impact of interest rate and exchange rate volatility on the performance of the informal sector in Nigeria, focusing on Small and Medium-sized Enterprises (SMEs). The annual time-series data on the exchange and interest rates for the period 1981-2018 were obtained from where exchange and interest rates volatility data were computed. The data analysis was carried out using descriptive statistics, correlation, a unit root test, an Autoregressive Distributed Lag (ARDL) bound test for cointegration and the ARCH regression model. The results obtained by the ARDL bound test confirmed the presence of the long-term relationship between interest and exchange rates volatility and SMEs' performance, which suggests that all the variables of interest move together in the long run. Moreover, the ARCH regression model showed a positive impact of exchange and interest rates volatility on SMEs' performance. However, only exchange rate volatility was significant. Thus, policy makers should pursue the interest rate and exchange rate regimes that will encourage massive investments in SMEs. This, in turn, would increase the performance of SMEs. Also, the monetary authorities should implement the policies aimed at curtailing incessant volatility in the exchange rate and the interest rate so as to protect SMEs from the external perturbations of the movements of the exchange rate and the interest rate.

Keywords: cointegration, exchange rate regimes, foreign exchange, macroeconomic policies, monetarism, structural adjustment program

JEL Classification: 017, C22, E52

\section{INTRODUCTION}

The informal sector of any economy describes the economic activities largely unregulated by the

* Correspondence to: O. H. Osahon, Department of Business Administration, Faculty of the Social Sciences, Delta State University, Abraka, Delta State, Nigeria;

e-mail: henryosas@yahoo.com government labor laws or taxation laws. It covers activities in agriculture, services, transportation, manufacturing, construction and commerce. This sector is always looked unto for economic sustenance by teeming job seekers. Globally, the sector is significant in improving countries' economies (Norhidayah \& Dzurizah, 2020). In the case of Nigeria, the Bank of Industry (2018) states that the informal 
sector comprises the "enterprises that are not officially registered and do not maintain a complete set of accounts; and workers who hold job lacking basic social or legal protection and employment benefits." This sector raked in approximately 65\% to the Gross Domestic Product (GDP) in 2017 (Bank of Industry, 2018). In connection with said, it is imperative for an intervention to be made in the sector in order to maximize its potentials.

In Africa, informal activities are not fully declared, which, however, has not stopped attempts at estimating their magnitude (Medina, Andrew \& Cangul, 2017). The estimates of the proportion of the contribution made by the informal sector to the GDP across African countries is put at above $40 \%$ compared to less than $20 \%$ in developed countries (Benjamin, Mbaye, Diop, Golub, Haughton \& Niang, 2012). For Ghana, M. A. Ocran (2018) submits that the size of the informal sector has maintained growth over the past decades from $14 \%$ of the GDP in the 1960s to 30\% in the 2000s, with an upward trend being envisaged. There is also a general consensus among development studies on Africa that the informal sector occupies a prominent position in their economies. Informal firms in the areas of transportation, carpentry, wholesale and retail trade, to mention but a few, dominate some of the largest and high-growth sectors of the West African economies.

As reported by N. Benjamin et al (2012), the informal sector acts as the last resort for employment for those who have few opportunities in the formal sector. A chunk of the new jobs created is by the informal sector. In Burkina Faso, for instance, the informal sector contributes $80 \%$ of the total employment (Steel \& Snodgrass, 2008). Employment in the informal sector is for the biggest part characterized by selfemployment, which accounts for $62 \%$ in North Africa and $70 \%$ in Sub-Saharan Africa on average. Trade liberalization in Africa and the implementation of the structural adjustment program (as in Burkina Faso and Nigeria) accentuated a rise in informal enterprises. Clearly, while the informal sector is a veritable source of income, the question remains as to whether it is a sustainable source for long-term growth and income generation.
Undoubtedly, SMEs constitute the core of the informal sector. Therefore, any intervention undertaken to integrate the informal sector into the formal sector must focus on SMEs. Nigerian SMEs face a lot of challenges, ranging from poor infrastructures and multiple taxation to unbalanced government macroeconomic policies, which have made it difficult for Nigerian SMEs to favorably compete in the global marketplace and meaningfully contribute to the percapita GDP. As opined by J. O. Adeniran, S. O. Yusuf and A. O. Adeyemi (2014), and corroborated by T. D. Edoko, S. C. Nwagbala and N. E. Okpala (2018), the issue of interest rate and exchange rate volatility (hereafter referred to as IERs) has been at the forefront of said challenges, which connotes that the volatility of IERs may portend a signaling effect on SMEs' performance.

O. Richard (2018) and W. A. Isola and E. P. Mesagan (2018) opined that the stability of an economy largely depends on macroeconomic dynamics, such as the exchange rate and the interest rate. The exchange rate refers to the price of a nation's currency in relation to another and plays a dominant role in any given economy as it affects the prices of imports and exports. The interest rate has also become an important part of economic discourse based on the fact that it facilitates the flow of funds from lenders to borrowers. The interest rate is a cost of borrowing and portrays what the borrower pays to the lender for using a credit.

Nigeria has gone through the diverse regimes of the exchange rate, ranging from the periods of no prescribed exchange rate during the period 19581959, the fixed exchange rate (which prevailed from late 1959 to June 1986) and the flexible exchange rate, which became effective in July 1986 and has been effective to date. Worthy of note is the fact that, while IERs vary, the exchange rate varies more quickly, usually on a day-to-day basis. Thus, IER volatility is the measure of the frequency at which the price of foreign exchange (forex) and interest rates changes over time. 


\section{PROBLEM STATEMENT}

\section{F. Okorontah and I. U. Odoemena (2016) submit} that exchange rate volatility causes panic in the forex market, because the traders and users of forex are unclear about what to envisage in the market on a daily basis. They could lose money if the exchange rate tumbles beneath their expectations, which sums up the predicaments that SMEs are confronted with in obtaining the forex needed to run their operations. In a similar fashion, the interest rate affects demand for and the allocation of loan funds, consumption, investment levels, and government borrowing, which has heightened the concern that the Central Bank of Nigeria (CBN) has been showing for a number of years in regulating the interest rate at which SMEs borrow (Central Bank of Nigeria, 2019).

Notwithstanding the progress made in financial economics and management, the literature on the volatility of IERs and the performance of SMEs in Nigeria and elsewhere shows that there seems to be no consistency in the literature concerning the nature and direction of the relationship (Osakwe, Verter, Becvarova \& Chovancova, 2015; Isola \& Mesagan, 2018; Udoh, Gbande, \& Acha, 2018). Even more so, separate analysis of the interest rate, on the one hand, and the exchange rate, on the other, have been carried out regarding SMEs' performance, a handful of studies having considered their joint effect. These studies have also used the nominal data about pertaining to the exchange rate or the interest rate on performance. This study extends the frontier of the analysis by not only looking at the combined effect of IERs on the performance of SMEs, but also the effect of their volatility on said performance. A volatility analysis provides us with an opportunity for the indepth examination of the effects of macroeconomic variables on performance. The relevance of this kind of study cannot be overemphasized, since the vibrant informal sector is a sine qua non for the realization of sustainable economic growth in any country. On this note, this study is of countless importance to the Nigerian economy since the nation is moving towards diversifying the economy away from crude oil.
Clearly, the dependence of the Nigerian economy on the informal sector, where a chunk of SMEs are found, warrants investigation into whether interest rate and exchange rate volatility affects the performance of SMEs in Nigeria. Accordingly, the research goals of this paper are to:

- investigate whether there is a significant influence of the interest rate and the interest rate volatility on SMEs' performance, and

- ascertain if the exchange rate and exchange rate volatility have a significant influence on the performance of SMEs.

From the foregoing, the hypotheses of the study are as follows:

- The interest rate and interest rate volatility have no positive significant effect on SMEs' performance,

- The exchange rate and exchange rate volatility have no positive significant impact on SMEs' performance.

These hypothetical propositions are tested using the autoregressive conditional heteroscedasticity (ARCH) model on the time-series data of the variables.

The remainder of this paper is structured into the following sections: in Section Two, a review of the related literature is presented, and in Section Three, the focus is on the methods. The empirical result is given in Section Four, and Section Five is the conclusion of the study including some recommendations.

\section{LITERATURE REVIEW}

\section{The perspectives of small and medium- sized enterprises}

The term SMEs has no universal delineation. The benchmarks for categorizing an enterprise as small, medium-sized or large differ from one country to another contingent on whether the country is developed or developing. In the Nigerian context, the 
term SMEs refers to enterprises with an aggregate capital employed of no less than 1.500 .000 naira, but not exceeding 200.000.000 naira, together with working capital, yet excluding the cost of land, and/or with the workforce of no fewer than 10 and no more than 300 (Ojeyinka, 2019). Globally, SMEs are pivotal in the GDP growth and unemployment reduction, which is so because they can navigate through challenging and changing economic environments. They are a framework for the development of entrepreneurial initiatives, which is essential for making an economy competitive (Robu, 2013; Zygmunt, 2017; Cicea, Popa, Marinescu, \& Stefan, 2019).

In developing economies, one of the key impairments to the performance of SMEs is access to loan funds from financial institutions and its relative cost (Owualahi, 2004). In a similar fashion, J. A. Ojo (2004) claimed that those impairments (access to loan funds, the exchange rate and the interest rate) usually diminished the performance of SMEs. According to R. M. Dada (2014), it endangers the aggregate performance of the economy. Consequently, SMEs are in a shamble state whenever IERs mitigate their performance.

\section{Exchange rate volatility and the performance of SMEs}

The Nigerian economy is largely dependent on crude oil, and fluctuations in oil prices portend a dire signal for the economy. Dwindling oil prices on the international market affect a foreign currency transaction and exchange rate volatility, which may affect the performance of SMEs. According to B. S. Omotosho (2015), the exchange rate is the nucleus of any economic stabilization program, as it links the general price level of an economy with other countries.

The exchange rate has two elements, namely the domestic currency and a foreign currency, and can be quoted both directly and indirectly. According to F. S. Udoh et al (2018), direct quotation is the price of the unit of a foreign currency expressed in terms of the local currency, whereas indirect quotation implies the reverse situation. These elements of the exchange rate are quoted in values against the US dollar and against another country's currency (cross-rates). Exchange rates can be either fixed or flexible. Nigeria operates a flexible exchange rate, which pegs the domestic currency to the US dollar, this being aimed at reducing volatility or improving trade dealings with other nations, since its main export is priced in the US dollar. N. Mohammad, N. Morteza, and S. Nadia (2018) opined that movements in the exchange rate exerted an influence on the performance of firms. The channels through which this can happen are as follows: export prices relative to overseas competitors, the cost of external borrowing and the cost of imported inputs in relation to other production inputs.

F. S. Udoh et al (2018) assert that, when SMEs are unable to access forex, their performance declines. S. Suleyman (2014) also argues that the performance of SMEs worsens as they become susceptible to the manipulations of the exchange rate because of their feeble bargaining position. With the compelling need for imported inputs, the issue of exchange rate volatility will continue to pose as a drawback to SMEs.

Given the growing need to provide employment and sustainable living for the teeming and growing Nigerian population, the Government has made concerted efforts towards stimulating the performance of SMEs. These efforts are evident in the series of the CBN's and other agencies' schemes and initiatives aimed at providing funds to SME operators. According to the Central Bank of Nigeria (2019), SMEs are the fundamental drivers of growth via their contribution to employment generation and poverty reduction. This justifies the attention paid to SMEs by the Government and other stakeholders in the Nigerian development project. There is only a hope that this attention will yield the desired results.

\section{Interest rate volatility and the performance of SMEs}

In Nigeria, lending to SMEs has been a vital concern of not only the Government, but other corporate 
bodies, such as the World Bank and the International Monetary Fund (IMF), and stakeholders in the country as well. The interest rate regime became effective in 1960, when the Nigerian Government had the sole authority to determine the interest rate via the monetary policies geared towards the development of and supporting the vital SME sectors of the economy (Ene, Agoke \& Ene, 2015). This concern came as the Government's methodical policy intended to expand the economy. However, there was a sharp twist when the trade liberalization policy that culminated in the introduction of the structural adjustment program (SAP) in 1986 was embraced.

According to O. J. Ifeanyi and N. G. Chukwu (2014) and E. Tajudeen, O. Taofeek, O. Ayinde and A. B. Abdul-Ganiy (2017), the SAP gave rise to the liberalization of the financial sector, leaving the interest rate to the dictates of demand and supply, the risk appetite of financial institutions, and consumers' negotiating dominance. This no doubt affected SMEs (Udoh et al, 2018). S. Suleyman (2014) opines that the performance of SMEs deteriorates as they become susceptible to interest rate volatility due to their weak negotiating strength.

\section{The theoretical framework}

The theoretical base of this study is anchored to monetarist theory, which is predominantly linked to the Nobel Prize winning economist Milton Friedman. Monetarist theory states that economic growth and the behavior of the business cycle largely depend on changes in money supply. A variation in money supply impacts on the output and price levels. While a short-term impact is exerted on the national output, a long-term impact is on price levels. Monetarism emphasizes the role the Government has in controlling money supply. Hence, monetary policies are designed to affect the output of an economy, which effect is made through the interest rate that alters the cost of capital and hence the investments in the productive sector that can be undertaken (Mishkin, 2007).

O. A. Uchendu (2006) states that variations in monetary policies influence the activities carried out by SMEs through the three major channels. The first channel is through liquidity, where the nominal interest rate changes liquidity conditions in the short run. The second channel is the credit channel, which works through banks' operations. The third channel is the exchange rate channel, which works through the forex market. Monetary adjustment is induced by the forex flow between countries, as stimulated by differentials in IERs. However, this takes place quickly if an economy's financial market is developed (Udoh et al, 2018). Clearly, in order to augment the aggregate performance of the economy's constituents (both the formal and the informal sectors), the Government uses macroeconomic variables, such as IERs, to adjust the amount of money in the economy. Because markets intuitively move towards an unwavering point, an imperfectly set money supply may cause a market to behave intermittently.

\section{An extant studies review}

There is the robust literature on the volatility of IERs and the performance of SMEs in developed countries. However, there is a dearth of extant studies in developing Sub-Saharan Africa, particularly so in the Nigerian context. C. I. Enekwe, M. M. Ordu and C. Nwoha (2013) analyzed the fluctuations of the exchange rate and the performance of the manufacturing sector in Nigeria using the timeseries data from 1985 to 2010. The regression results showed that foreign private investment (a proxy for the dependent variable) was positively and significantly affected by exchange rate volatility in the manufacturing sector. E. A. Akinlo and V. A. Adejumo (2014) tested the impact of exchange rate volatility on non-oil exports using the quarterly data spanning from 1986 (Q1) to 2008 (Q4). The error correction model (ECM) and the vector autoregressive (VAR) model revealed that exchange rate volatility positively and significantly affected Nigeria's non-oil exports.

C. N. Osakwe et al (2015) examined macroeconomic variables and growth in the SMEs in the Czech Republic. The study did not find a significant influence of the domestic credit granted by the financial sector on the growth of SMEs. It, however, reported a 
positive association between economic growth and SME growth. In a similar fashion, L. O. Atarere, (2016) investigated the influence monetary policies had on the growth of SMEs in Nigeria. Worthy of note is the fact that this study was conceptual in nature and had no empirical base. Nevertheless, the study concluded that monetary policies significantly influenced the growth of SMEs. C. F. Okorontah and I. U. Odoemena (2016) explored the effects of the variation of the exchange rate on economic growth by means of the yearly time-series data obtained for the period 19862012. The OLS results and the ECM support no robust association between the exchange rates and economic growth .

E. S. Nsofo, S. M. Takson and S. U. Ugwuegbe (2017) investigated the extent to which exchange rate volatility influenced economic growth during for the period 1981-2015. The GARCH results revealed that exchange rate volatility and foreign direct investments had a negative impact on economic growth. F. S. Udoh et al (2018) examined the monetary policy on the growth of SMEs using the IER macroeconomic variables during the period 1986-2016. The ARCH regression results indicated that there was a significant impact of IERs on the growth of SMEs in Nigeria. In a related study, T. D. Edoko et al (2018) used the OLS framework and found the exchange rate to statistically explain the performance of SMEs.

O. Ipinnaiye, D. Dineea and H. Leniham (2017) examined the growth of the manufacturing SMEs in Ireland using the GMM estimation technique on the data of the census of industrial production for the period from 1991 to 2007. The results indicated that the macroeconomic environment directly and indirectly influenced the growth of a firm and also that that integrated with the characteristics and strategy of a firm.

T. E. Olatunji and O. R. Ibukun-Falayi (2018) evaluated the effects of the interest rate regulation on credit administration to SMEs during the period from 1994 to 2013. The results of the t-test and the analysis of the variance showed that the interest rate regulation had insignificant effects on credit administration to SMEs in Nigeria. W. A. Isola and E.P. Mesagan
(2018) examined the effect of the monetary policy on the performance of SMEs in Nigeria, Gambia and Ghana using data from 1981 to 2016. The study found a positive effect of IERs on the SME output for Nigeria although only the exchange rate variable was significant. For Gambia, the exchange rate was positive, but not significant, whereas the interest rate had a negative and significant effect on the output. In the case of Ghana, the exchange rate had a negative influence on the output, but the interest rate was positive. However, neither variable was statistically significant.

A study by O. T. Ojeyinka (2019) ascertained the impact of exchange rate volatility on the performance of the manufacturing sector during the period 19812016. Yearly time-series data were used and the ARDL estimation technique was applied alongside the bound test for cointegration. The findings showed that exchange rate volatility positively and significantly influenced the performance of the manufacturing sector.

\section{RESEARCH METHODS}

The ex-post facto design was adopted in this paper. It was used since the study seeks to establish the dynamics connected with a certain occurrence by analyzing the past events of the already existing conditions, where the dynamics cannot be changed. The secondary data were obtained and computed from the CBN's Statistical Bulletin and the National Bureau of Statistics (NBS) during the period 19812018. The interest rate, the exchange rate, interest rate and exchange rate volatility, and investments in SMEs are the variables used in the study.

SME investment was used as a proxy for the performance of the SMEs, which has already been used in prior studies (Okorontah \& Odoemena, 2016; Nsofo et al, 2017; Olatunji \& Ibukun-Falayi, 2018). Given the fact that this study assesses the effects of the volatility of IERs on the performance of SMEs, the $\mathrm{ARCH}$ methodology was adopted, the $\mathrm{ARCH}$ model being based on the $\mathrm{ARCH}(\mathrm{q})$ model, which 
provides the variance of a series using its prior variance (Gujarati, 2003). Given the fact that the $\mathrm{ARCH}$ model estimates the current value of a variable as determined by its prior value(s), the study used the equations (1) and (2) for that estimation:

$Y=\lambda_{0}+\lambda_{1} X_{t}+\mu_{t}$

$\sigma_{t}^{2}=\alpha_{0}+\sum_{q=1}^{k} \alpha_{1} \mu_{t-q}^{2}$

Equation (1) estimates the mean volatility, whereas Equation (2) estimates the variance model. The ARCH model consists of the mean and variance equations estimated in the form of a simultaneous equation. Nevertheless, an emphasis is placed on the variance equation due to its fitness to the forecast volatility. $\sigma_{t}^{2}$ is the current volatility, $\alpha_{1}$, the parameter gauging the effect of its lagged value (i.e. $\mu_{t-q}$ ). Given the equations (1) and (2), the ARCH model is estimated as:

$\sigma_{t}^{2}=\lambda_{0}+\sum_{i=1}^{q} \alpha_{i} \varepsilon_{t i}^{2}+\sum_{j=1}^{p} \beta_{j} \sigma_{t-j}^{2}$

$\sigma_{t}^{2}$ is the current volatility, $\alpha_{i}$, the parameter gauging the effect of the prior residual (i.e. $\varepsilon_{t i}^{2}$ ), while $\beta_{j}$ is the effect of the variation in its lagged value $\left(\sigma_{t-j}{ }^{2}\right)$.

Thus, the functional form of the model for this study can explicitly be expressed as:

Smeinv $=f($ Intrate, Intratevol, Exchrate, Exchratevol $)$

where:

Smeinv $=$ SME investments,

Intrate $=$ the interest rates,

Intratevol $=$ interest rate volatility.

Exchrate = the exchange rates,

Exchratevol $=$ exchange rate volatility.

In order to estimate the equations (1) and (2), it is translated into equation (5):

$$
\begin{aligned}
\text { Smeinv } & =m_{0}+A_{1} \text { Intrate }_{t-1}+A_{2} \text { Intratevol }_{t-1} \\
& +A_{3} \text { Exchrate }_{t-2}+A_{4} \text { Exchratevol }_{t-2}+\epsilon_{t}
\end{aligned}
$$

Given the fact that the study data are time series in nature and, moreover, that SME investments are expressed in billions of naira, while the other variables are expressed in percentages, SME investments were transformed into their natural logarithm in order to avoid an issue related to the scaling problem. In view of this, the equation (5) is recast as:

$$
\begin{aligned}
\text { Lsmeinv } & =m_{0}+A_{1} \text { Intrate }_{t-1}+A_{2} \text { Intratevol }_{t-1} \\
& +A_{3} \text { Exchrate }_{t-2}+A_{4} \text { Exchratevol }_{t-2}+\epsilon_{t}
\end{aligned}
$$

In order to reach the percent volatility of the interest rates (Intratevol), the study computed percent volatility as:

Intratevol $=\left(\right.$ Intr $\left.r_{t}-\operatorname{Intr}_{t-1}\right) /$ Intr ${ }_{t-1}$

where:

$I n t r_{t}=$ the interest rates in the current period,

$I n t r_{t-1}=$ the interest rates in the prior period.

In a similar fashion, the percent volatility of the exchange rate Exchratevol was computed as:

Exchratevol $=\left(\right.$ Exch $_{t}-$ Exchr $\left._{t-1}\right) /$ Exchr $_{t-1}$

where:

Exch $r_{t}=$ the exchange rates in the current period,

Exchr $_{t-1}=$ the exchange rates in the prior period.

Econometric tests were conducted in order of precedence: the Augmented Dickey-Fuller unit root test; the cointegration, over-parameterized and parsimonious error correction and diagnostic and $\mathrm{ARCH}$ tests.

\section{EMPIRICAL RESULTS}

The examination of the descriptive statistics of the used data series is the first step in any empirical inquiry. This precisely examined the mean, median, kurtosis, skewness and Jarque-Bera statistics of the variables so as to gain an insight into the distributional properties and normality of the data. This result is shown in Table 1.

The evidence presented in Table 1 indicates some level of consistency in the data series as the mean and the median lie within the minimum value and the maximum value for all the variables. The mean values 
are 2.97, 17.59, 0.005, 88.54 and -0.12 for Lssmeinv, Intrate, Intratevol, Exchrate, and Exhratevol, respectively, with the corresponding standard deviation of 0.74 , 4.6, 0.21, 87.14 and 0.18, respectively. Likewise, the skewness, the kurtosis and the Jarque-Bera statistics jointly offer information on the normality of the data series. It can be seen that the null hypothesis of normal distribution cannot be rejected for all the variables (Lssmeinv, Intrate, Exchrate, and Exhratevol) based on the Jarque-Bera statistics, except for Intratevol, since the probability value is greater than 0.05 . Thus, Intratevol satisfies the normality condition. This further leads to the assessment of the likelihood of multicollinearity among the variables in the model, as is presented in Table 2 .

According to Table 2, there is no multicollinearity among the variables in the empirical model, since no interrelation among the pairs of the independent variables exceeds the value 0.8 (Jeroh, 2020). Moreover, none of the variables is negatively correlated with the performance of SMEs, which is not alarming as a decrease in the lending rate encourages investment, and positively affects the performance of SMEs by the extension. Additionally, a decrease in the exchange rates will positively affect the performance of SMEs, which follows the a priori expectation. Given the fact that there is no multicollinearity among the pairs of the independent variables, the unit root test was conducted via the Augmented Dickey-Fuller (ADF) and Phillip-Perron (PP) unit root tests (Table 3) before estimating the ARDL.

The result of the ADF and PP unit root tests follows the expectations. All the variables (Lsmeinv, Intrate, Intratevol, Exchrate, Exchratevol) were stationery at the first difference order I(1), sets the pace for the next stage of the ARDL test.

Table 1 The descriptive statistics of the data series

\begin{tabular}{l|ccccc}
\hline Statistics & Lsmeinv & Intrate & Intratevol & Exchrate & Exchratevol \\
\hline Mean & 2.9662 & 17.5924 & 0.0005 & 88.5442 & -0.1226 \\
Median & 2.6469 & 17.5250 & 0.0073 & 97.020 & -0.0682 \\
Maximum & 4.0054 & 29.8000 & 0.6266 & 306.08 & 0.0612 \\
Minimum & 2.0712 & 7.7500 & -0.4000 & 0.62000 & -0.7629 \\
Std. Dev. & 0.7361 & 4.6264 & 0.2127 & 87.1369 & 0.1823 \\
Skewness & 0.2998 & 0.19405 & 0.54672 & 0.80295 & -1.8651 \\
Kurtosis & 1.4073 & 3.6713 & 4.0356 & 2.9743 & 6.1188 \\
Jarque-Bera & 3.803 & 1.645 & 1.514 & 3.613 & 4.582 \\
Probability & 0.000 & 0.050 & 0.064 & 0.000 & 0.000 \\
\hline Obs. & 38 & 38 & 38 & 38 & 38 \\
\hline
\end{tabular}

Source: Author

Table 2 The correlation matrix of the data series

\begin{tabular}{|c|c|c|c|c|c|}
\hline Variables & Lsmeinv & Intrate & Intratevol & Exchrate & Exchratevol \\
\hline Lsmeinv & 1.0000 & & & & \\
\hline Intrate & 0.0027 & 1.0000 & & & \\
\hline Intratevol & 0.0793 & -0.2789 & 1.0000 & & \\
\hline Exchrate & 0.7034 & 0.0799 & 0.0349 & 1.0000 & \\
\hline Exchratevol & 0.3122 & -0.2451 & 0.3574 & 0.1819 & 1.0000 \\
\hline
\end{tabular}

Source: Author 
In Table 4, the ADRL bound test method proposed by H. Pesaran, Y. Shin and R. Smith (2001) reveals that the computed F-statistics are greater than the upper critical bound I(1), thus indicating that the null hypothesis of non-co-integration is rejected. Consequently, the empirical result confirms the presence of the long-term relationship between IER volatility and the performance of SMEs in Nigeria. This result is further supported by the time-series line plots presented as Figure 1.

The result shown in Figure 1 demonstrates that the SME investment plots (Lsmeinv) and the exchange rate (Exchrate) move in a similar trend, whereas the variables of the interest rate, exchange rate volatility (Exchratevol) and interest rate volatility (Intratevol) move in the same direction, which is indicative of the fact that our empirical model is stable and does not suffer from structural variability over the study period. Finally, the ARCH result is presented in Table 5.
Table 5 captures the ARCH regression estimators for the performance of SMEs (Lsmeinv) and exchange rate volatility (Exchratevol) and interest rate volatility (Intratevol). The parameters for Intratevol and Exchratevol are 0.0227 and 0.1477 , respectively. However, only the exchange rate is significant at the $1 \%$ level. The ARCH parameters are also statistically significant. Hence, the null hypothesis of no ARCH(1) effects is rejected, which clearly indicates the ARCH effect of IER volatility on the performance of SMEs in Nigeria. Additionally, the study finds that the effect of IER volatility on the performance of SMEs is both positive and significant (Wald chi2 $(2)=1084.74$ ). Likewise, the effect of the first and second year lags in the exchange rate and the interest rate positively affects the performance of SMEs in Nigeria. Based on these results, the hypotheses of the study are rejected. These results are consistent with $\mathrm{W}$. A. Isola and E. P. Mesagan (2018) and O. T. Ojeyinka (2019), but the same are contradictory to C. N. Osakwe et al (2015).

Table 3 The summary of the unit root tests (ADF\&PP) and the trend

\begin{tabular}{l|ccc|ccc}
\hline & \multicolumn{3}{|c|}{ ADF Test } & \multicolumn{3}{c}{ PP Test } \\
\hline Variables & Level & $1^{\text {st }}$ Diff. & Order & Level & $1^{\text {st }}$ Diff & Order \\
Lsmeinv & -0.249 & $-3.682^{* * *}$ & $\mathrm{I}(1)$ & -0.258 & $-3.668^{* * *}$ & $\mathrm{I}(1)$ \\
Intrate & -2.449 & $-3.682^{* * *}$ & $\mathrm{I}(1)$ & -3.483 & $-3.668^{* * *}$ & $\mathrm{I}(1)$ \\
Intratevol & -3.509 & $-3.682^{* * *}$ & $\mathrm{I}(1)$ & -9.164 & $-3.668^{* * *}$ & $\mathrm{I}(1)$ \\
Exchrate & 0.872 & $-3.682^{* * *}$ & $\mathrm{I}(1)$ & 1.531 & $-3.668^{* * *}$ & $\mathrm{I}(1)$ \\
Exchratevol & -2.850 & $-3.682^{* * *}$ & $\mathrm{I}(1)$ & -4.715 & $-3.668^{* * *}$ & $\mathrm{I}(1)$ \\
\hline
\end{tabular}

Note: " denotes 'statistically significant' at the $1 \%$ level; ${ }^{* *}$ denotes 'statistically significant' at the $5 \%$ level; and ${ }^{* * *}$ denotes 'statistically significant' at the $10 \%$ level.

Source: Author

Table 4 The ARDL bound tests for co-integration

\begin{tabular}{ccc}
\hline Variables & F-statistic & Co-integration \\
\hline $\mathrm{F}($ Lsmeinv, Intrate, Intratevol, Exchrate, Exchratevol) & 6.23 & Co-integration \\
\hline Critical Values & Lower Bound & Upper Bound \\
$1 \%$ & 2.93 & 4.69 \\
$5 \%$ & 2.56 & 3.86 \\
$10 \%$ & 2.24 & 3.45 \\
\hline
\end{tabular}

Source: Author 


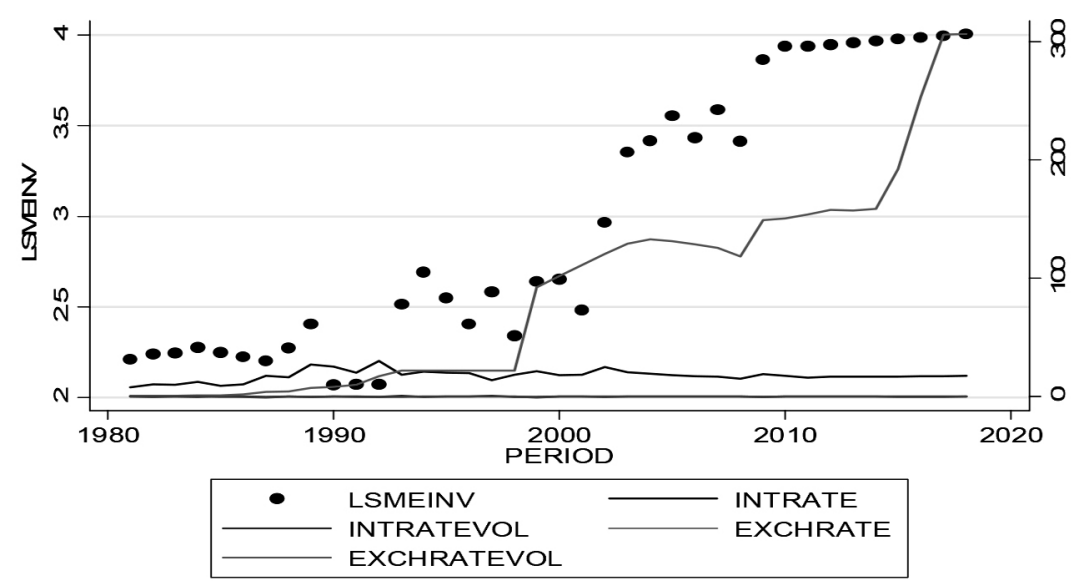

Figure 1 The time-series line plot of the variables used in the study

Source: Author

Table 5 ARCH regression

\begin{tabular}{|c|c|c|c|c|c|c|}
\hline \multicolumn{3}{|c|}{$\begin{array}{c}\text { Sample: } 1981 \text { - } 2018 \\
\text { Distribution: Gaussian } \\
\text { Log likelihood }=4.977193\end{array}$} & \multicolumn{4}{|c|}{$\begin{array}{c}\text { Number of obs. }=38 \\
\text { Wald chi2 }(2)=1084.74 \\
\text { Prob }>\text { chi2 }=0.0000\end{array}$} \\
\hline \multicolumn{7}{|c|}{ OPG } \\
\hline & Coef. & Std. Err. & $z$ & $P>z$ & [95\% Conf. & Interval] \\
\hline Intrate & .0025001 & .0015623 & 1.60 & 0.110 & -.000562 & .0055622 \\
\hline Intratevol & .0227908 & .0706671 & 0.32 & 0.747 & -.1157141 & .1612958 \\
\hline Exchrate & .0088609 & .0003206 & 27.64 & $0.000^{*}$ & .0082326 & .0094892 \\
\hline Exchratevol & .147745 & .0523291 & 2.82 & $0.005^{*}$ & .045182 & .2503081 \\
\hline _cons & 2.240598 & .0404797 & 55.35 & 0.000 & 2.161259 & 2.319937 \\
\hline \multicolumn{7}{|c|}{ ARCH } \\
\hline L1. & 1.623442 & .6816684 & 2.38 & $0.017^{* *}$ & .2873966 & 2.959488 \\
\hline L2. & .8958968 & .5386714 & 1.66 & $0.096^{* * *}$ & -.1598798 & 1.951673 \\
\hline _cons & -.0000943 & .0018317 & -0.05 & 0.959 & -.0036843 & .0034957 \\
\hline
\end{tabular}

Note: * denotes 'statistically significant' at the $1 \%$;** denotes 'statistically significant at the $5 \%$ level; and *** denotes 'statistically significant at the $10 \%$ level.

Source: Author

\section{CONCLUSION}

In this paper, the effect of IER volatility on the performance of SMEs in Nigeria for the period from 19812018 was investigated. Yearly time series data were used. The data were analyzed using descriptive statistics, a correlation matrix, the unit root test, the ARDL bound tests for co-integration and the ARCH regression model. First, the ARDL bound test results confirm the existence of the long-term relationship between interest rate volatility and exchange rate volatility and the performance of SMEs, which is 
symptomatic of all the variables moving together in the long run. Second, the ARCH model reveals that the impact of IER volatility on the performance of SMEs is positive and with a significant impact coming from the exchange rate and exchange rate volatility.

The significant value of the exchange rate implies that Nigerian SMEs react more to perturbations in the exchange rate and, consequently, the external factors that are outside the domestic economy. It shows that these SMEs use more of the imported inputs that require forex to acquire. Therefore, the thrust of policy is to redirect SMEs towards looking inward for inputs as a way to curtail their demand for forex. Policy makers should manage the interest rate and exchange rate regimes so as to encourage massive investments in SMEs. In addition, the monetary authorities should implement the policies aimed at curtailing the incessant volatility of the exchange rate and the interest rate.

Notwithstanding the efforts this study has made, the same is still limited by the number of the analyzed variables. For instance, only one measure of performance was used. To extend this discourse, it is suggested that further studies should use a mix of performance proxies in addition to the other macroeconomic variables, which will help to test whether the results are sensitive to the adopted performance measures.

\section{REFERENCES}

Adeniran, J. O., Yusuf, S. O., \& Adeyemi, A. O. (2014). The impact of exchange rate fluctuation on the Nigerian economic growth: An empirical investigation. International Journal of Academic Research in Business and Social Sciences, 4(8), 224-233. doi:10.6007/ijarbss/v4-i8/1091

Akinlo, E. A., \& Adejumo, V. A. (2014). Exchange rate volatility and non-oil exports in Nigeria: 1986-2008. International Business and Management, 9(2), 70-79. doi.org/10.3968/\%25x

Atarere, L. O. (2016). Influence of monetary policies on the growth of the small and medium scale enterprises. International Journal of Innovative Finance and Economics Research, 4(2), 8-15.
Bank of Industry. (2018). Economic development through the Nigerian informal sector: A BOI perspective. Working Paper Series; No 2.

Benjamin, N., Mbaye, A. A., Diop, I. A. T., Golub, S. S., Haughton, D., \& Niang, B. B. (2012). The Informal Sector In Francophone Africa: Firm Size, Productivity, And Institutions. African Development Forum: A co publication of the Agence Francaise de developpement and World Bank, 4871. doi:10.1596/978-0-8213-9537-0

Central Bank of Nigeria. (2019). Statistical Bulletin. Abuja, NG: Central Bank of Nigeria Publication.

Cicea, C., Popa, I., Marinescu, C., \& Stefan, S. C. (2019). Determinants of SMEs' performance: Evidence from European countries. Economic Research-Ekonomska Istrazivanja, 32(1), 1602-1620. doi.org/10.1080/133167 7X.2019.1636699

Dada, R. M. (2014). Commercial banks' credit and SMEs development in Nigeria: An empirical review. International Journal of Research, 1(8), 305-320.

Edoko, T. D., Nwagbala, S. C., \& Okpala, N. E. (2018). Impact of exchange rate on the performance of Small and Medium Enterprises in Nigeria. International Journal of Trend in Scientific Research and Development, 2(4), 1553-1559.

Ene, E. E., Agoke, S. A., \& Ene, C. J. (2015). Effect of interest rates deregulation on the performance of deposit money banks in Nigeria. International Journal of Managerial Studies and Research, 3(9), 164-176.

Enekwe, C. I., Ordu, M. M., \& Nwoha, C. (2013). Effect of exchange rate fluctuations on manufacturing sector in Nigeria. European Journal of Business and Management, 5(22), 67-73.

Gujarati, D. (2003). Basic econometrics. New York, NY: McGrawHill Inc.

Ifeanyi, O. J., \& Chukwu, N. G. (2014). The nexus of interest rate deregulation and economic growth in Nigeria. International Journal of Empirical Finance, 3(3), 142-151.

Ipinnaiye, O., Dineea, D., \& Leniham, H. (2017). Drivers of SME performance: A holistic and multivariate approach. Small Business Economics, 48(4), 883-911. doi:10.1007/s11187016-9819-5 
Isola, W. A., \& Mesagan, E. P. (2018). Monetary policy and small and medium enterprises' performance in selected West African countries. The Romanian Economic Journal, 21(69), 14-23.

Jeroh, E. (2020). An assessment of the internal determinants of the environmental disclosure practices of firms across SubSaharan Africa. Economic Horizons, 22(1), 43-54. doi:10.5937| ekonhor2001047J

Medina, L., Andrew, J., \& Cangul, M. (2017). The informal economy in Sub Saharan Africa: Size and determinants. IMF Working Paper.

Mishkin, F. S. (2007). Housing and the monetary transmission. NBER Working paper No 13518.

Mohammad, N., Morteza, N., \& Nadia, S. (2018). Impact of exchange rate movements on Indian firm performance. International Journal of Finance and Accounting, 7(4), 108-121. doi:10.5923/j.ijfa.20180704.03

Norhidayah, H., \& Dzurizah, I. (2020). Employment relations in the informal sector: A need for redefinition. Humanities and Social Sciences Letters, 8(4), 397-406. doi:10.18488/ journal.73.2020.84.397.406

Nsofo, E. S., Takson, S. M., \& Ugwuegbe, S. U. (2017). Modeling exchange rate volatility and economic growth in Nigeria. Noble International Journal of Economics and Financial Research, 2(6), 88-97.

Ocran, M. A. (2018). Estimating the size and trends of the informal economy in Ghana. Working Papers from African Economic Research Consortium, Nairobi, November.

Ojeyinka, O. T. (2019). Exchange rate volatility and the performance of manufacturing sector in Nigeria (1981-2016). African Journal of Economic Review, 7(2), 27-41. doi:10.22004/ ag.econ. 292357

Ojo, J. A. (2004). Reforms the Nigerian financial system of industrial transformation. Paper presented at the National Workshop on financial liberation and growth in developing economics: A reassessment. Organized by Nigeria Society for Financial Research (NSFR) $10^{\text {th }}-12^{\text {th }}$ November 2004, University of Lagos.

Okorontah, C. F., \& Odoemena, I. U. (2016). Effects of exchange rate fluctuations on economic growth of Nigeria. International Journal of Innovative Finance and Economics Research, 4(2), 1-7.
Olatunji, T. E., \& Ibukun-Falayi, O. R. (2018). The effect of interest rate regulation on credit extension to SMEs in Nigeria. International Journal of Research in Business Management, 6(5), 17-30.

Omotosho, B. S. (2015). Is real exchange rate misalignment a leading indicator of currency crises in Nigeria? CBN Journal of Applied Statistics, 6(1), 153-179.

Osakwe, C. N., Verter, N., Becvarova, V., \& Chovancova, M. (2015). SMEs growth in the Czech Republic: Some macroeconomic perspectives. Acta Universitatis Agriculturae et Silviculturae Mendelinae Brunensis, 63(6), 2077-2084. doi:10.11118/actaun201563062077

Owualahi, S. I (2004). Financial liberation and the availability of credit to small and medium enterprises in Nigeria. A paper presented at the national workshop on financial liberation and growth in developing economics: A re-assessment. Organized by Nigeria Society for Financial Research (NSFR) $10^{\text {th }}-12^{\text {th }}$ November 2004, University of Lagos.

Pesaran, H., Shin, Y., \& Smith, R. (2001). Bounds testing approaches to the analysis of level relationships. Journal of Applied Econometrics, 16(3), 289-326. doi.org/10.1002/jae.616

Richard, O. (2018). Effect of interest rate mechanisms on the economic development of Nigeria, 1986-2016. IIARD International Journal of Economics and Business Management, $4(4), 91-115$.

Robu, M. (2013). The dynamic and importance of SMES in economy. USV Annals of Economics and Public Administration, 13(1), 84-89.

Steel, W. F., \& Snodgrass, D. (2008). World Bank region analysis on the informal economy: In raising productivity and reducing risk of household enterprises annex 1. Diagnostic Methodology Framework, Washington, DC: Word Bank.

Suleyman, S. (2014). The effects of the monetary policies on bank credit for SME's in the manufacturing sector: Evidence from Turkey. Istanbul Chamber of Commerce Department of $S M E^{\prime}$ s.

Tajudeen, E., Taofeek, O., Ayinde, O., \& Abdul-Ganiy, A. B. (2017). Interest rate liberalization, financial development and economic growth in Sub- Saharan African economies. African Journal of Economic Review, 5(2), 1-17. doi:10.22004/ ag.econ. 264568

Uchendu, O. A. (2006). The transmission of monetary policy in Nigeria. Economic and Financial Review, 34(2), 606-625. 
Udoh, F. S., Gbande, C., \& Acha, I. A. (2018). Monetary policy and growth of small and medium enterprises in Nigeria. International Journal of Advanced Studies in Business Strategies and Management, 6(1), 39-60.
Zygmunt, A. (2017). Innovation activities of Polish firms: Multivariate analysis of the moderate innovator countries. Oeconomia Copernicana, 8(4). 505-521. doi.org/10.24136/ oc.v8i4.31

Received on $9^{\text {th }}$ December 2020, after revision, accepted for publication on $15^{\text {th }}$ April 2021

Published online on $23^{\text {rd }}$ April 2021.

Osazevbaru Henry Osahon, Ph.D, is a lecturer in the Department of Business Administration, Faculty of the Social Sciences, Delta State University, Abraka Delta State, Nigeria. 


\title{
UTICAJ NEPOSTOJANOSTI KAMATNIH STOPA I KURSA NA UČINAK NEFORMALNOG SEKTORA U NIGERIJI: PRIMER MALIH I SREDNJIH PREDUZEĆA
}

\author{
Henry Osahon Osazevbaru \\ Department of Business Administration, Faculty of the Social Sciences, Delta State University, \\ Abraka, Nigeria
}

U ovom radu se istražuje zajednički uticaj nepostojanosti kamatnih stopa i kursa na učinak neformalnog sektora u Nigeriji, s fokusom na mala i srednja preduzeća. Godišnji podaci vremenskih serija kursa i kamatnih stopa, za period 1981-2018, pribavljeni su iz centara u kojima se vrši izračunavanje nepostojanosti kursa i kamatnih stopa. Podaci su analizirani pomoću deskriptivne statistike, korelacije, testa jediničnog korena, testa graničnih vrednosti autoregresivnih distribuiranih docnji (ARDL) za kointegraciju i ARCH regresionog modela. Rezultat testa graničnih vrednosti autoregresivnih distribuiranih docnji potvrdio je postojanje dugoročne veze između nepostojanosti kamatnih stopa i kursa, s jedne, i učinka malih i srednjih preduzeća, s druge strane, što sugeriše da se sve relevantne varijable dugoročno kreću u istom smeru. Štaviše, ARCH regresioni model je pokazao da nepostojanost kamatnih stopa i kursa pozitivno utiče na učinak malih i srednjih preduzeća. Međutim, samo je nepostojanost kursa bila značajna. Stoga bi donosioci politika trebalo da slede režime kamatnih stopa i kursa koji će podstaći velika ulaganja u mala i srednja preduzeća, što bi zauzvrat povećalo učinak malih i srednjih preduzeća. Monetarne vlasti bi, takođe, trebalo da sprovode politike koje imaju za cilj smanjenje neprekidne nepostojanosti kursa i kamatnih stopa kako bi se mala i srednja preduzeća zaštitila od eksternih poremećaja trendova kursa i kamatnih stopa.

Ključne reči: kointegracija, režimi kursa, devize, makroekonomske politike, monetarizam, program strukturnog usaglašavanja

JEL Classification: 017, C22, E52 